Article

\title{
Crystal Structures of Two 1,4-Diamino-1,2,4-triazolium Salts
}

\author{
Gerhard Laus ${ }^{1, *}$, Klaus Wurst ${ }^{1}$, Volker Kahlenberg ${ }^{2}$ and Herwig Schottenberger ${ }^{1}$ \\ Received: 30 December 2015; Accepted: 18 January 2016; Published: 20 January 2016 \\ Academic Editor: Helmut Cölfen \\ 1 Faculty of Chemistry and Pharmacy, University of Innsbruck, 6020 Innsbruck, Austria; \\ klaus.wurst@uibk.ac.at (K.W.); herwig.schottenberger@uibk.ac.at (H.S.) \\ 2 Institute of Mineralogy and Petrography, University of Innsbruck, 6020 Innsbruck, Austria; \\ volker.kahlenberg@uibk.ac.at \\ * Correspondence: gerhard.laus@uibk.ac.at; Tel.: +43-512-507-57080; Fax: +43-512-507-57099
}

\begin{abstract}
Bis(1,4-diamino-1,2,4-triazolium) sulfate (1) was obtained from the corresponding chloride by ion metathesis using $\mathrm{Ag}_{2} \mathrm{SO}_{4}$. Further metathesis with barium 5,5'-azotetrazolate yielded bis(1,4-diamino-1,2,4-triazolium) 5,5'-azotetrazolate (2). Numerous $\mathrm{NH} \cdots \mathrm{N}$ and $\mathrm{NH} \cdots \mathrm{O}$ interactions were identified in the crystal structures of $\mathbf{1}$ and $\mathbf{2}$. Both compounds undergo exothermal decomposition upon heating.
\end{abstract}

Keywords: azotetrazolate; hydrogen bond; sulfate; thermoanalysis; triazolium

\section{Introduction}

$\mathrm{N}$-Aminoazoles are pillars of heterocyclic chemistry, and interest in $\mathrm{N}$-aminoazoles and their salts ranges from agrichemistry to medicinal chemistry. In particular, $N, N^{\prime}$-diaminoazolium salts exhibited attractive biological activities [1]. Thus far, the crystal structure of only one 1,4-diamino-1,2,4-triazolium salt, the chloride, has been published [2]. One of the most exciting developments are nitrogen-rich salts. The synthesis of sodium 5,5'-azotetrazolate was first reported by Thiele [3]. A lot has happened since then in terms of compound synthesis and developments, and a number of salts containing 5,5'-azotetrazolate ions and their crystal structures have been described [4-6]. One can still find small and simple molecules that are neglected in the literature. The 1,4-diamino-1,2,4-triazolium cation is one of those missing links. Bis(1,4-diamino-1,2,4-triazolium) $5,5^{\prime}$-azotetrazolate was reported to spontaneously evolve nitrogen gas and to undergo violent decomposition at $134{ }^{\circ} \mathrm{C}$ [7], but no crystal structure was disclosed. Recently, the structure of the closely related bis(1,3-diaminoimidazolium) 5,5'-azotetrazolate was determined [8]. Here, we report the crystal structures of bis(1,4-diamino-1,2,4-triazolium) 5,5'-azotetrazolate and its precursor, bis(1,4-diamino-1,2,4-triazolium) sulfate.

\section{Results and Discussion}

The synthesis of bis(1,4-diamino-1,2,4-triazolium) sulfate (1) was accomplished by metathesis of the corresponding chloride with silver sulfate (Figure 1). In a second metathetical step of the sulfate 1 and barium 5,5'-azotetrazolate, bis(1,4-diamino-1,2,4-triazolium) 5,5'-azotetrazolate (2) was obtained. Both steps gave high yields ( $90 \%$ and $98 \%$, respectively). It should be noted that $\mathrm{N}$-aminoazoles and $\mathrm{N}$-aminoazolium salts which are not derived from hydrazine have to be prepared by electrophilic amination. They are therefore expensive and only of academic interest.

$N, N^{\prime}$-Diaminoazolium cations are potent hydrogen bond donors [2,8-10], and it seemed to be of interest to examine the interactions of the 1,4-diamino-1,2,4-triazolium cation with acceptor anions 
such as sulfate or 5,5'-azotetrazolate in the solid state. The crystal data and refinement details are summarized in Table 1.<smiles></smiles><smiles>[O-]</smiles><smiles>CC(C)(Cl)[Mg]OS(=O)(=O)O</smiles><smiles>CCCCCCCC</smiles>
2<smiles></smiles>

1<smiles>[O-]n1nnnc1/N=N/c1nnn[nH]1</smiles>

Figure 1. Syntheses of 1,4-diamino-1,2,4-triazolium sulfate (1) and 5,5'-azotetrazolate (2).

Table 1. Crystal data and structure refinement for $\mathbf{1}$ and 2.

\begin{tabular}{|c|c|c|}
\hline Compound & 1 & 2 \\
\hline CCDC No. & 1441522 & 1441523 \\
\hline Empirical formula & $2\left(\mathrm{C}_{2} \mathrm{H}_{6} \mathrm{~N}_{5}\right) \cdot \mathrm{O}_{4} \mathrm{~S}$ & $2\left(\mathrm{C}_{2} \mathrm{H}_{6} \mathrm{~N}_{5}\right) \cdot \mathrm{C}_{2} \mathrm{~N}_{10}$ \\
\hline Formula weight & 296.30 & 364.36 \\
\hline Crystal system & Monoclinic & Monoclinic \\
\hline Space group & $P_{C}$ & $P 2_{1} / c$ \\
\hline$a / \AA$ & 11.0114(3) & $3.5735(3)$ \\
\hline$b / \AA$ & $8.4671(2)$ & $14.8270(12)$ \\
\hline$c / \AA$ & $12.8156(5)$ & 13.4559(11) \\
\hline$\beta /{ }^{\circ}$ & $92.356(3)$ & $95.664(3)$ \\
\hline Volume $/ \AA^{3}$ & $1193.85(6)$ & $709.47(10)$ \\
\hline Z & 4 & 2 \\
\hline$D_{x} / \mathrm{g} \cdot \mathrm{cm}^{-3}$ & 1.648 & 1.706 \\
\hline$\mu / \mathrm{mm}^{-1}$ & 0.31 & 0.13 \\
\hline$F(000)$ & 616 & 376 \\
\hline $\mathrm{T} / \mathrm{K}$ & 173 & 183 \\
\hline Crystal size $/ \mathrm{mm}^{3}$ & $0.54 \times 0.20 \times 0.16$ & $0.18 \times 0.04 \times 0.03$ \\
\hline$\theta_{\max } /^{\circ}$ & 25.4 & 25.0 \\
\hline Index ranges & $\begin{array}{l}-13 \leqslant h \leqslant 11 \\
-10 \leqslant k \leqslant 10 \\
-14 \leqslant l \leqslant 15\end{array}$ & $\begin{array}{c}-4 \leqslant h \leqslant 3 \\
-17 \leqslant k \leqslant 17 \\
-15 \leqslant l \leqslant 15\end{array}$ \\
\hline Reflections collected & 7080 & 9515 \\
\hline Independent reflections $\left(R_{\text {int }}\right)$ & $3571(0.028)$ & $1250(0.060)$ \\
\hline Observed reflections $[I>2 \sigma(I)]$ & 3428 & 1001 \\
\hline Absorption correction & multi-scan & multi-scan \\
\hline Restraints/parameters & $18 / 392$ & $4 / 135$ \\
\hline Goodness-of-fit on $F^{2}$ & 1.09 & 1.06 \\
\hline$R_{1} / w R_{2}[I>2 \sigma(I)]$ & $0.026 / 0.077$ & $0.037 / 0.092$ \\
\hline$R_{1} / w R_{2}$ (all data) & $0.029 / 0.079$ & $0.052 / 0.098$ \\
\hline$\Delta \rho_{\max } / \Delta \rho_{\min } / \mathrm{e} . \AA^{-3}$ & $0.23 /-0.25$ & $0.54 /-0.22$ \\
\hline
\end{tabular}




\subsection{Bis(1,4-diamino-1,2,4-triazolium) Sulfate (1)}

Hydrogen atoms at N3 and N5 were found and refined isotropically. The geometry of the N-amino groups was pyramidal, indicating $\mathrm{sp}^{3}$ hybridization. The $N$-amino group conformations relative to the azolium ring planes were eclipsed (lone pair closely aligned with the ring plane, $\mathrm{N}-\mathrm{H}$ bonds out of the ring plane), as observed in the structure of the corresponding chloride (Cambridge Structural Database reference code MEBPOZ).

The crystal structure of this simple salt was found to be unexpectedly complicated. There are four independent cations and two anions in the asymmetric unit. Numerous $\mathrm{NH} \cdots \mathrm{O}$ hydrogen bonds (Table 2) create a three-dimensional framework. These interactions are depicted separately, for the sake of clarity, for each of the four independent cations $A-D$ in Figure 2.

Table 2. Hydrogen bond geometry for $\mathbf{1}$ and $2\left(\AA,^{\circ}\right)$.

\begin{tabular}{|c|c|c|c|c|c|}
\hline Compound & Interaction & $\mathbf{H} \cdots A$ & $D \cdots A$ & $D-\mathbf{H} \cdots A$ & $\begin{array}{c}\text { Symmetry } \\
\text { Operation } A\end{array}$ \\
\hline \multirow{19}{*}{1} & $\mathrm{~N} 5_{A}-\mathrm{H} 51_{A} \cdots \mathrm{O} 5$ & $2.04(2)$ & $2.913(3)$ & $160(3)$ & $x, y, z$ \\
\hline & $\mathrm{N} 5{ }_{A}-\mathrm{H} 52_{A} \cdots \mathrm{O} 3$ & $2.04(2)$ & $2.946(3)$ & $173(3)$ & $x, y, z$ \\
\hline & $\mathrm{N} 3{ }_{C}-\mathrm{H} 31_{C} \cdots \mathrm{O} 1$ & 2.11(3) & $3.008(3)$ & $169(3)$ & $x, y, z$ \\
\hline & $\mathrm{N} 3{ }_{C}-\mathrm{H} 31_{C} \cdots \mathrm{O} 3$ & $2.48(3)$ & $3.115(3)$ & $128(3)$ & $x, y, z$ \\
\hline & $\mathrm{N} 3_{\mathrm{C}}-\mathrm{H} 32_{\mathrm{C}} \cdots \mathrm{O} 5$ & 2.19(3) & $2.962(4)$ & $144(3)$ & $x,-y,-1 / 2+z$ \\
\hline & $\mathrm{N} 3_{\mathrm{B}}-\mathrm{H} 31_{\mathrm{B}} \cdots \mathrm{O} 2$ & $2.15(2)$ & $2.932(3)$ & $145(3)$ & $x, 1+y, z$ \\
\hline & $\mathrm{N} 3_{\mathrm{B}}-\mathrm{H} 32_{\mathrm{B}} \cdots \mathrm{O} 7$ & $2.07(2)$ & $2.951(3)$ & $172(3)$ & $1+x, y, z$ \\
\hline & $\mathrm{N} 5_{\mathrm{D}}-\mathrm{H} 51_{\mathrm{D}} \cdots \mathrm{O} 8$ & $2.06(3)$ & $2.871(3)$ & $151(3)$ & $x, y, z$ \\
\hline & $\mathrm{N} 5_{D}-\mathrm{H} 52_{\mathrm{D}} \cdots \mathrm{O} 2$ & $2.16(2)$ & $2.996(3)$ & 155(3) & $-1+x, y, z$ \\
\hline & $\mathrm{N} 3{ }_{D}-\mathrm{H} 31_{D} \cdots \mathrm{O} 1$ & $2.00(2)$ & $2.889(3)$ & $163(3)$ & $x, y, z$ \\
\hline & $\mathrm{N} 3_{\mathrm{D}}-\mathrm{H} 32_{\mathrm{D}} \cdots \mathrm{O} 5$ & $2.16(2)$ & $3.042(4)$ & $170(3)$ & $x,-1+y, z$ \\
\hline & $\mathrm{N} 5{ }_{B}-\mathrm{H} 51_{B} \cdots \mathrm{O} 4$ & $2.14(2)$ & $2.989(4)$ & $162(3)$ & $x,-y,-1 / 2+z$ \\
\hline & $\mathrm{N} 55_{B}-H 52_{B} \cdots N 3_{A}$ & $2.26(2)$ & $3.108(4)$ & $159(3)$ & $x,-y,-1 / 2+z$ \\
\hline & $\mathrm{N} 5{ }_{C}-\mathrm{H} 52_{C} \cdots \mathrm{O} 5$ & 2.11(3) & $2.922(4)$ & $152(3)$ & $x, 1-y,-1 / 2+z$ \\
\hline & $\mathrm{N} 3_{\mathrm{A}}-\mathrm{H} 31_{\mathrm{A}} \cdots \mathrm{O} 6$ & $2.03(2)$ & $2.874(3)$ & $157(3)$ & $1+x, y, z$ \\
\hline & $\mathrm{N} 3{ }_{\mathrm{A}}-\mathrm{H} 32_{\mathrm{A}} \cdots \mathrm{O} 2$ & $1.98(2)$ & $2.856(3)$ & $166(3)$ & $x,-y, 1 / 2+z$ \\
\hline & $\mathrm{N}_{3}-\mathrm{H} 32_{\mathrm{B}} \cdots \mathrm{O} 8$ & $2.54(3)$ & $3.123(3)$ & $124(2)$ & $1+x, y, z$ \\
\hline & $\mathrm{N} 5{ }_{C}-\mathrm{H} 51_{C} \cdots \mathrm{O} 1$ & $2.56(3)$ & $3.353(3)$ & $150(3)$ & $x, 1+y, z$ \\
\hline & $\mathrm{N} 5 \mathrm{C}-\mathrm{H} 51_{\mathrm{C}} \cdots \mathrm{N} 3_{\mathrm{D}}$ & $2.68(3)$ & $3.301(4)$ & $129(2)$ & $x, 1+y, z$ \\
\hline \multirow{4}{*}{2} & $\mathrm{~N} 10-\mathrm{H}_{\mathrm{A}} \cdots \mathrm{N} 3$ & $2.12(2)$ & $3.018(2)$ & $169(2)$ & $x, y, z$ \\
\hline & $\mathrm{N} 10-\mathrm{H}_{\mathrm{B}} \cdots \mathrm{N} 1$ & $2.16(2)$ & $3.048(2)$ & $167(2)$ & $x, 3 / 2-y,-1 / 2+z$ \\
\hline & $\mathrm{N} 8-\mathrm{H}_{\mathrm{A}} \cdots \mathrm{N} 2$ & $2.38(2)$ & $3.152(2)$ & $146(2)$ & $1-x, 1-y, 1-z$ \\
\hline & $\mathrm{N} 8-\mathrm{H}_{\mathrm{B}} \cdots \mathrm{N} 4$ & $2.64(3)$ & $3.221(2)$ & $125(2)$ & $-x,-1 / 2+y, 1 / 2-z$ \\
\hline
\end{tabular}

\subsection{Bis(1,4-diamino-1,2,4-triazolium) 5,5'-Azotetrazolate (2)}

The salt $\left(\mathrm{C}_{2} \mathrm{H}_{6} \mathrm{~N}_{5}\right)_{2}\left(\mathrm{C}_{2} \mathrm{~N}_{10}\right)$ consists of 76.9 percent nitrogen and thus can be rightly considered to be "nitrogen-rich." The hydrogen atoms at N8 and N10 were found and refined isotropically with bond restraints, and the $N$-amino groups again are pyramidal. The ions form cyclic hydrogen-bonded assemblies (Figure 3), which can be described by a $R_{2}^{2}(13)$ graph set [11], meaning a 13-membered ring with 2 hydrogen bond donors and 2 acceptors. In contrast, in the structure of the related 1,3-diaminoimidazolium 5,5'-azotetrazolate (CSD reference code YEHTAI) [8] hydrogen bonds between two cations and two anions create centrosymmetric ring-shaped aggregates, graph set $R_{4}^{4}(20)$. In 2, a wave-like arrangement of the ions is observed (Figure 3), whereas the very similar salt, 4-amino-1-methyl-1,2,4-triazolium 5,5'-azotetrazolate (CSD reference code PAPMOJ), packed in flat layers and crystallized in an orthorhombic space group [7]. Obviously, the structure of 2 is controlled by the additional hydrogen bonding of the second amino group. 


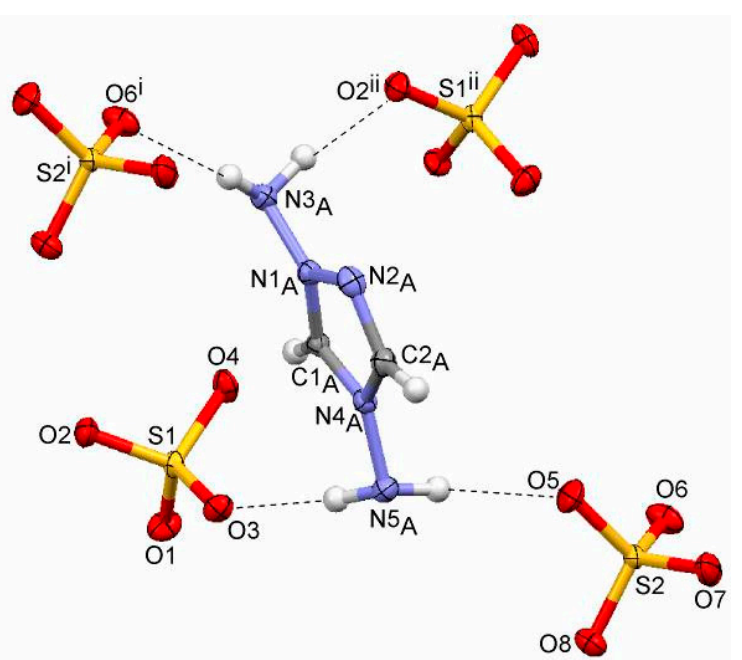

(a)

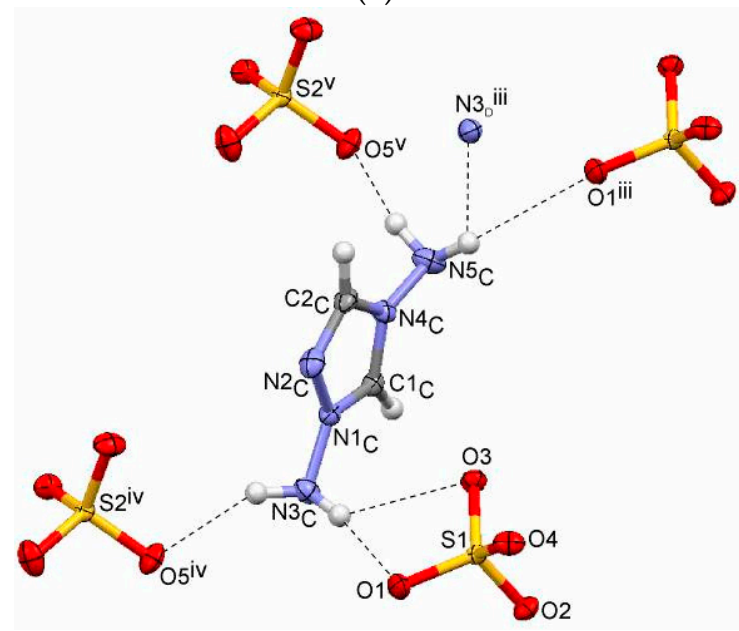

(c)

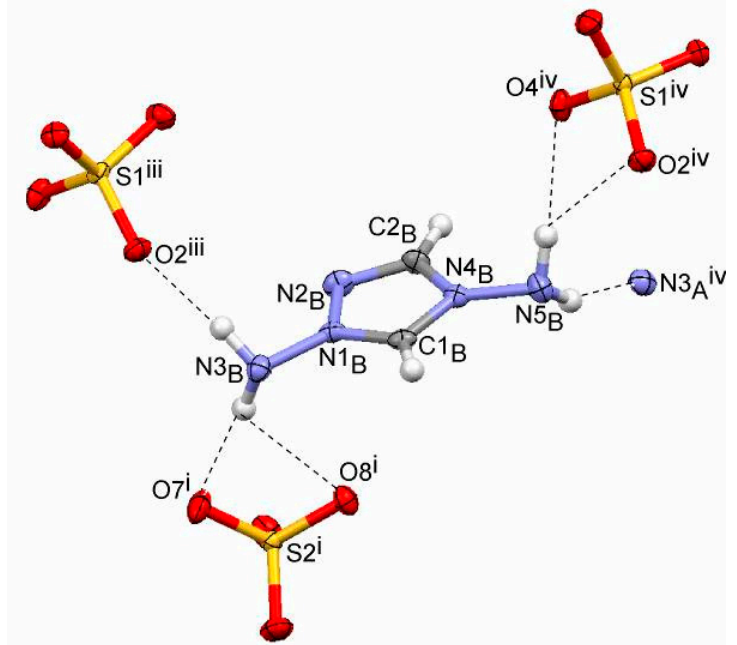

(b)

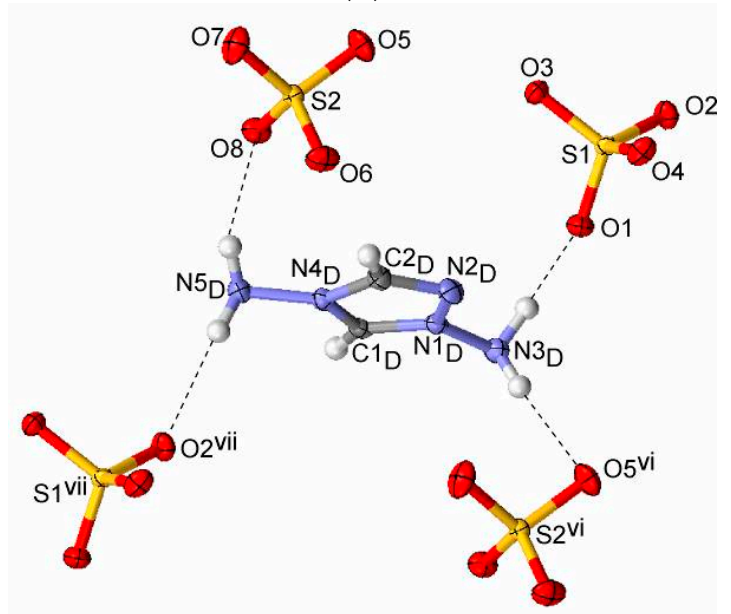

(d)

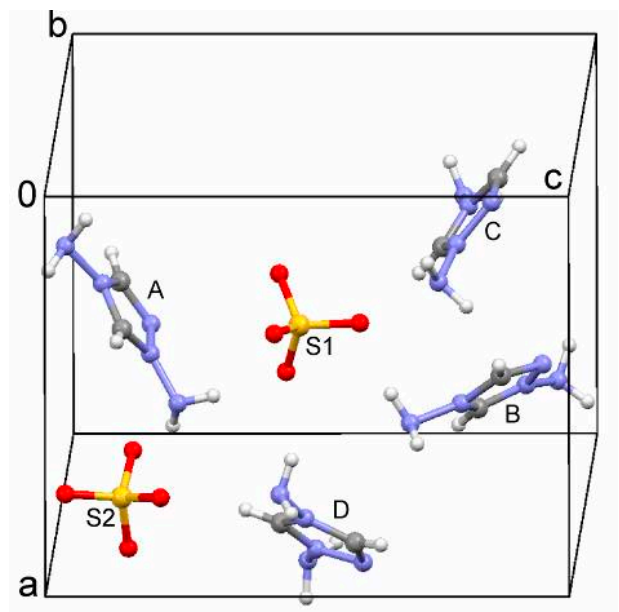

(e)

Figure 2. Bis(1,4-diamino-1,2,4-triazolium) sulfate (1). (a-d) The four independent cations as hydrogen-bond donors. Symmetry codes: (i) $1+x, y, z$; (ii) $x,-y, 1 / 2+z$; (iii) $x, 1+y$, $z$; (iv) $x,-y$, $-1 / 2+z$; (v) $x, 1-y,-1 / 2+z$; (vi) $x,-1+y, z$; (vii) $-1+x, y, z$; (e) Asymmetric unit. 


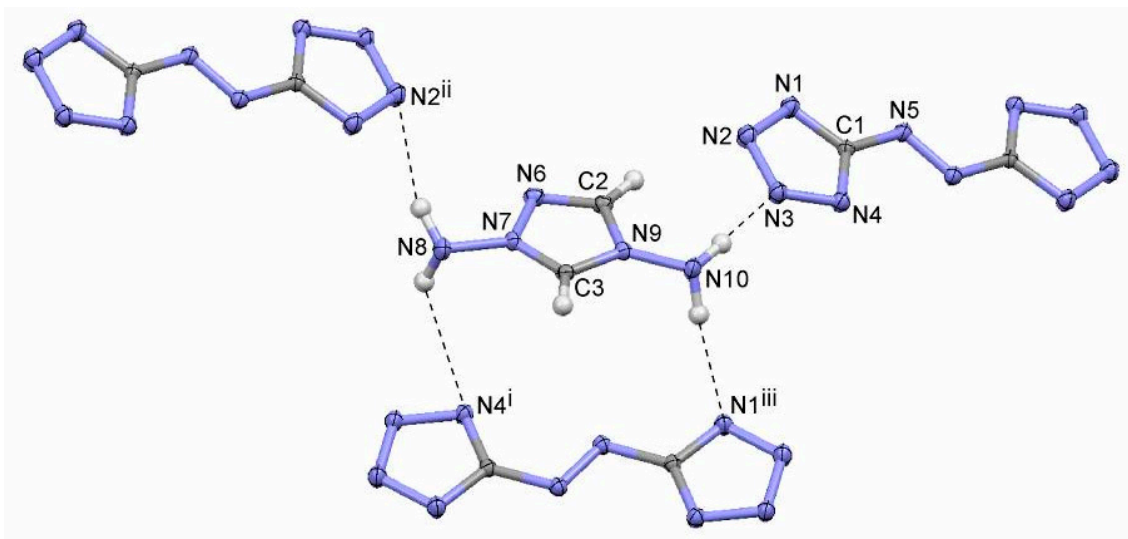

(a)

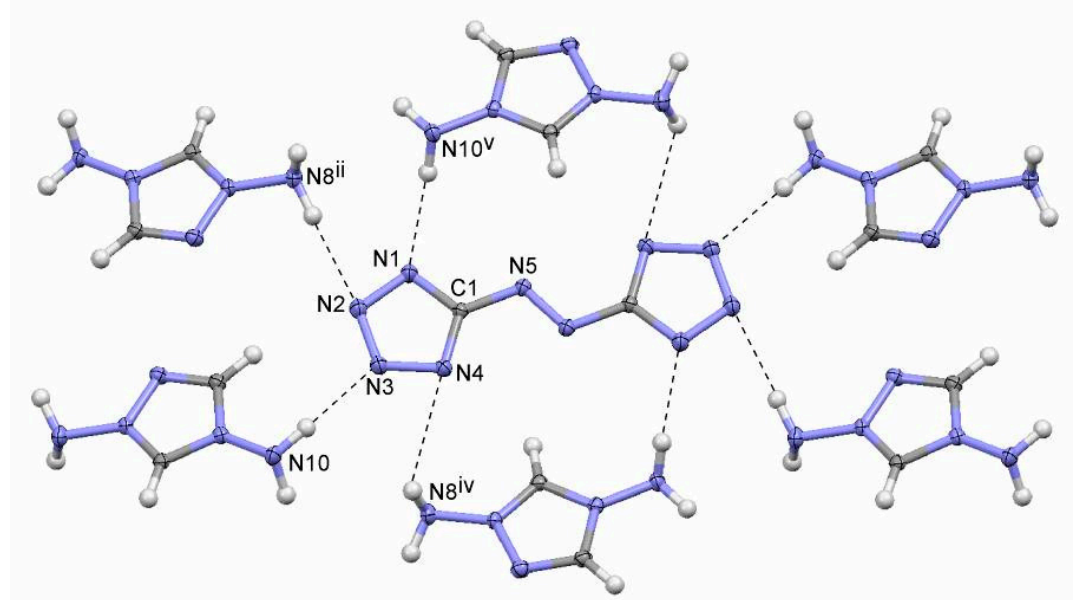

(b)

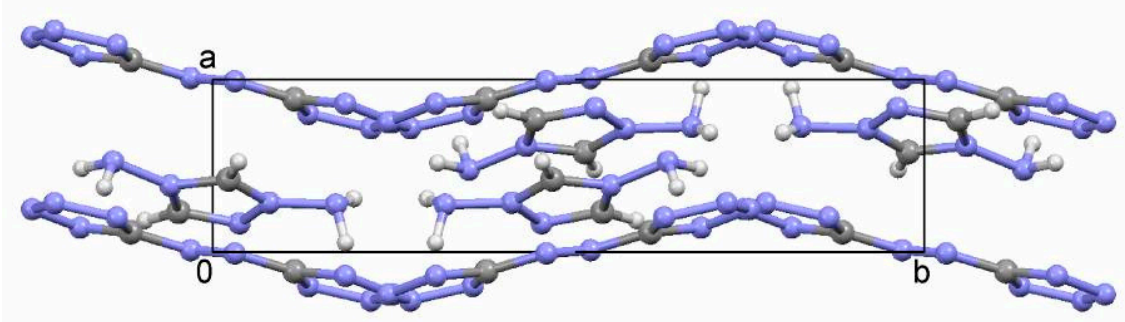

(c)

Figure 3. Bis(1,4-diamino-1,2,4-triazolium)5,5'-azotetrazolate (2). (a) The cation as hydrogen-bond donor; (b) The anion as hydrogen-bond acceptor; (c) Wave-like arrangement of the ions in the unit cell. Symmetry codes: (i) $-x,-1 / 2+y, 1 / 2-z$; (ii) $1-x, 1-y, 1-z$; (iii) $x, 3 / 2-y,-1 / 2+z$; (iv) $-x, 1 / 2+y$, $1 / 2-z$; (v) $x, 3 / 2-y, 1 / 2+z$.

\subsection{Differential Scanning Calorimetry (DSC) and Thermogravimetric Analysis (TGA)}

Thermoanalysis of the triazolium salts $\mathbf{1}$ and $\mathbf{2}$ showed initial melting followed by exothermal decomposition (maxima at 164 and $165^{\circ} \mathrm{C}$ ) with approximately $60 \%$ loss of mass. Decomposition gases are not limited to $\mathrm{N}_{2}$, but also include $\mathrm{NH}_{3}, \mathrm{CH}_{4}$ and $\mathrm{HCN}$ [6], which are formed in varying amounts. Thermograms are depicted in Figure 4. 


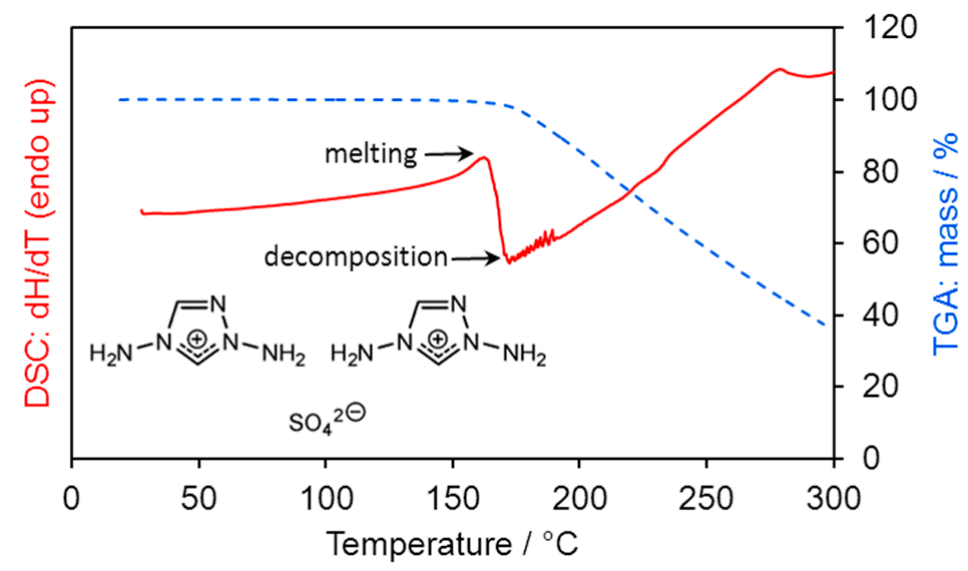

(a)

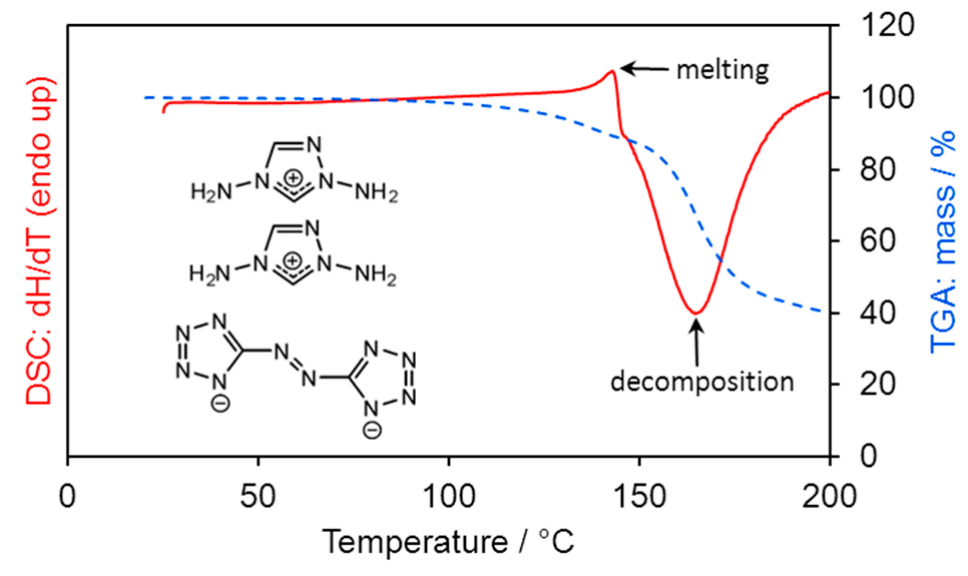

(b)

Figure 4. DSC and TGA of (a) bis(1,4-diamino-1,2,4-triazolium) sulfate (1) and (b) 5,5'-azotetrazolate (2). Heating rate $10^{\circ} \mathrm{C} \cdot \mathrm{min}^{-1}$.

\section{Experimental Section}

1,4-Diamino-1,2,4-triazolium chloride [CASRN 122583-43-1] was prepared as previously described [12]. Barium 5,5'-azotetrazolate pentahydrate [CASRN 441747-65-5] was prepared according to a published procedure [13]. All other chemicals were purchased from Sigma-Aldrich (Steinheim, Germany). NMR spectra were recorded with a Bruker Avance DPX 300 spectrometer (Billerica, MA, USA). IR spectra were obtained with a Bruker Alpha FT (Billerica, MA, USA) instrument. DSC was performed with a DSC 7 (Perkin-Elmer, Norwalk, CT, USA) applying a heating rate of $10^{\circ} \mathrm{C} \cdot \mathrm{min}^{-1}$. TGA was carried out with a TGA 7 system (Perkin-Elmer) at a heating rate of $10^{\circ} \mathrm{C} \cdot \mathrm{min}^{-1}$.

Single crystal diffraction intensity data were recorded by $\omega$ scans with an Oxford Diffraction Gemini-R Ultra (Oxford Diffraction Ltd., Abingdon, Oxfordshire, UK) or by $\varphi$ and $\omega$ scans with a Bruker D8 Quest Photon 100 (Billerica, MA, USA) diffractometer using MoK $\alpha$ radiation. CCDC reference numbers: 1441522 and 1441523 . These data can be obtained free of charge from The Cambridge Crystallographic Data Centre (Cambridge, UK).

\subsection{Bis(1,4-diamino-1,2,4-triazolium) Sulfate (1)}

A solution of 1,4-diamino-1,2,4-triazolium chloride $(0.65 \mathrm{~g}$, $4.8 \mathrm{mmol})$ in hot $\mathrm{H}_{2} \mathrm{O}(30 \mathrm{~mL})$ was added to a solution of $\mathrm{Ag}_{2} \mathrm{SO}_{4}(0.75 \mathrm{~g}, 2.4 \mathrm{mmol})$ in hot $\mathrm{H}_{2} \mathrm{O}(60 \mathrm{~mL})$. The mixture was sonicated for 10 minutes, and the precipitate was removed by centrifugation. The supernatant was taken to 
dryness under reduced pressure, and the residue was crystallized from hot $\mathrm{MeOH}$. Single crystals were obtained by slow diffusion of $\mathrm{MeOH}$ into a $\mathrm{H}_{2} \mathrm{O} / 2-\mathrm{PrOH}$ solution. Yield: $0.64 \mathrm{~g}(90 \%)$. M.p. $151-154{ }^{\circ} \mathrm{C}$ (decomposition). ${ }^{1} \mathrm{H}$ NMR (DMSO-d $\left.6,300 \mathrm{MHz}\right): \delta 6.9$ (br s, 2H), 7.4 (br s, 2H), $9.06(\mathrm{~s}, 1 \mathrm{H})$, 10.20 (s, 1H) ppm. IR (neat): $\widetilde{v} 3216(\mathrm{~m}), 3119(\mathrm{~m}), 2991(\mathrm{~m}), 1646(\mathrm{w}), 1409(\mathrm{w}), 1053(\mathrm{~s}), 985(\mathrm{~m})$, $974(\mathrm{~m}), 901(\mathrm{~m}), 751(\mathrm{w}), 652(\mathrm{w}), 605(\mathrm{~s}), 488(\mathrm{~m}) \mathrm{cm}^{-1}$.

\subsection{Bis(1,4-diamino-1,2,4-triazolium) 5,5'-Azotetrazolate (2)}

A solution of bis(1,4-diamino-1,2,4-triazolium) sulfate (50 mg, $0.17 \mathrm{mmol})$ in $\mathrm{H}_{2} \mathrm{O}(2 \mathrm{~mL})$ was added to a suspension of barium 5,5'-azotetrazolate pentahydrate $(66 \mathrm{mg}, 0.17 \mathrm{mmol})$ in $\mathrm{H}_{2} \mathrm{O}(4 \mathrm{~mL})$. The mixture was stirred at $20^{\circ} \mathrm{C}$ for $72 \mathrm{~h}$, and the precipitate was removed by filtration through a $0.45 \mu \mathrm{m}$ filter. The clear filtrate was taken to dryness at $20^{\circ} \mathrm{C}$ under reduced pressure $(0.1 \mathrm{mbar})$ to yield a yellow powder $(60 \mathrm{mg}, 98 \%)$. Single crystals were obtained by slow diffusion of $\mathrm{Et}_{2} \mathrm{O}$ into a MeOH solution. M.p. $135{ }^{\circ} \mathrm{C}$ (decomposition). ${ }^{1} \mathrm{H}$ NMR (DMSO-d $\left.6,300 \mathrm{MHz}\right): \delta 7.05(\mathrm{~s}, 2 \mathrm{H})$, 7.46 (s, 2H), $9.10(\mathrm{~s}, 1 \mathrm{H}), 10.28$ (s, 1H) ppm. ${ }^{13} \mathrm{C} \mathrm{NMR}$ (DMSO-d $\left.{ }_{6}, 75 \mathrm{MHz}\right): \delta 140.9,143.5,173.3 \mathrm{ppm}$. IR (neat): $\widetilde{v} 3313(\mathrm{w}), 3213(\mathrm{w}), 3171(\mathrm{w}), 3085(\mathrm{~m}), 2998(\mathrm{~m}), 2919(\mathrm{~m}), 1627(\mathrm{~m}), 1442(\mathrm{~m}), 1390(\mathrm{~s})$, $1171(\mathrm{~m}), 1159(\mathrm{~m}), 1081(\mathrm{~m}), 1047(\mathrm{~m}), 1019(\mathrm{~s}), 953(\mathrm{~s}), 897(\mathrm{~m}), 732(\mathrm{~s}), 650(\mathrm{~s}), 625(\mathrm{~s}), 608(\mathrm{~s}) \mathrm{cm}^{-1}$.

\section{Conclusions}

One can still find small and simple molecules which are neglected in the literature-in other words, hidden treasures. The 1,4-diamino-1,2,4-triazolium cation is one of those. Intricate networks of hydrogen bonds are observed in the crystal structures of two nitrogen-rich salts.

Author Contributions: Gerhard Laus conceived and designed this study, carried out experimental work (synthesis, crystallization and characterization) and wrote the manuscript. Klaus Wurst and Volker Kahlenberg determined the crystal structures. Herwig Schottenberger contributed conceptual details and supported this study.

Conflicts of Interest: The authors declare no conflict of interest.

\section{References}

1. Link, H.; Klötzer, W.; Karpitschka, E.M.; Montavon, M.; Müssner, R.; Singewald, N. 1-Amino-and 1,3-Diaminoimidazolium Salts. Angew. Chem. Int. Ed. Engl. 1990, 29, 556-557. [CrossRef]

2. Laus, G.; Kahlenberg, V.; Többens, D.M.; Jetti, R.K.R.; Griesser, U.J.; Schütz, J.; Kristeva, E.; Wurst, K.; Schottenberger, H. Lattice architecture and hydrogen-bonding networks of $\mathrm{N}$-aminoazolium and N,N'-diaminoazolium chlorides. Cryst. Growth Des. 2006, 6, 404-410. [CrossRef]

3. Thiele, J. Ueber Azo- und Hydrazoverbindungen des Tetrazols. Ann. Chem. 1898, 303, 57-75. (In German). [CrossRef]

4. Laus, G.; Kahlenberg, V.; Wurst, K.; Schottenberger, H.; Fischer, N.; Stierstorfer, J.; Klapötke, T.M. Synthesis and crystal structures of new 5,5'-azotetrazolates. Crystals 2012, 2, 127-136. [CrossRef]

5. Lampl, M.; Laus, G.; Braun, D.E.; Kahlenberg, V.; Wurst, K.; Fuhrmann, G.; Schottenberger, H.; Huppertz, H. New crystal structures in the realm of 5,5'-azotetrazolates. Z. Naturforsch. 2015, 70, 125-134. [CrossRef]

6. Klapötke, T.M.; Sabaté, C.M. New energetic compounds based on the nitrogen-rich $5,5^{\prime}$-azotetrazolate anion $\left(\left[\mathrm{C}_{2} \mathrm{~N}_{10}\right]^{2-}\right)$. New J. Chem. 2009, 33, 1605-1617. [CrossRef]

7. Ye, C.; Xiao, J.-C.; Twamley, B.; Shreeve, J.M. Energetic salts of azotetrazolate, iminobis(5-tetrazolate) and 5,5'-bis(tetrazolate). Chem. Commun. 2005, 21, 2750-2752. [CrossRef] [PubMed]

8. Laus, G.; Wurst, K.; Schottenberger, H. Crystal structure of bis(1,3-diaminoimidazolium) 5,5'-azotetrazolate, $\left(\mathrm{C}_{3} \mathrm{H}_{7} \mathrm{~N}_{4}\right) 2\left(\mathrm{C}_{2} \mathrm{~N}_{10}\right), \mathrm{C}_{8} \mathrm{H}_{14} \mathrm{~N}_{18}$. Z. Kristallogr. New Cryst. Struct. 2012, 227, 293-294. [CrossRef]

9. Laus, G.; Kahlenberg, V.; Schottenberger, H. Crystal structure of 1,3-diaminoimidazolium hexafluorophosphate, $\left[\mathrm{C}_{3} \mathrm{H}_{7} \mathrm{~N}_{4}\right] \mathrm{PF}_{6}$. Z. Kristallogr. New Cryst. Struct. 2010, 225, 463-464. [CrossRef]

10. Bentivoglio, G.; Schwärzler, A.; Wurst, K.; Kahlenberg, V.; Nauer, G.; Bonn, G.; Schottenberger, H.; Laus, G. Hydrogen Bonding in the Crystal Structures of New Imidazolium Triflimide Protic Ionic Liquids. J. Chem. Cryst. 2009, 39, 662-668. [CrossRef] 
11. Bernstein, J.; Davis, R.E.; Shimoni, L.; Chang, N.-L. Patterns in Hydrogen Bonding: Functionality and Graph Set Analysis in Crystals. Angew. Chem. Int. Ed. Engl. 1995, 34, 1555-1573. [CrossRef]

12. Laus, G.; Klötzer, W. Synthesis of 1-amino-1H-1,2,4-triazoles. Synthesis 1989, 4, 269-272. [CrossRef]

13. Hammerl, A.; Holl, G.; Klapötke, T.M.; Mayer, P.; Nöth, H.; Piotrowski, H.; Warchhold, M. Salts of 5,5'-azotetrazolate. Eur. J. Inorg. Chem. 2002, 4, 834-845. [CrossRef]

(c) 2016 by the authors; licensee MDPI, Basel, Switzerland. This article is an open access article distributed under the terms and conditions of the Creative Commons by Attribution (CC-BY) license (http:/ / creativecommons.org/licenses/by/4.0/). 